Portland State University

PDXScholar

$1-1-2010$

\title{
Anatomy of Mishima's Most Successful Play Rokumeikan
}

Mami Harano

Portland State University

Follow this and additional works at: https://pdxscholar.library.pdx.edu/open_access_etds Let us know how access to this document benefits you.

\section{Recommended Citation}

Harano, Mami, "Anatomy of Mishima's Most Successful Play Rokumeikan" (2010). Dissertations and Theses. Paper 387.

https://doi.org/10.15760/etd.387

This Thesis is brought to you for free and open access. It has been accepted for inclusion in Dissertations and Theses by an authorized administrator of PDXScholar. Please contact us if we can make this document more accessible: pdxscholar@pdx.edu. 


\title{
Anatomy of Mishima's Most Successful Play Rokumeikan
}

by

\section{Mami Harano}

A thesis submitted in partial fulfillment of the requirements for the degree of

\author{
Master of Arts \\ in \\ Japanese
}

Thesis Committee:

Laurence Kominz, Chair

Patricia Wetzel

Suwako Watanabe

Portland State University

(C)2010 


\begin{abstract}
Mishima Yukio premiered the play Rokumeikan in 1956 and published it in 1957. For more than half a century, this play has been praised as one of the finest Japanese plays in the Post-War period. Rokumeikan is a multi-act tragic melodrama, set in 1886 (Meiji Period) in the Rokumeikan building. The play intertwines complex political cabals, intense loves and hatreds, and multiple deceptions embodying the conflict between political power and love. This essay explores the reasons why Rokumeikan has maintained its popularity over its fifty year long performance history and examines the critical reception of the play. My analysis of the Rokumeikan text is based on conflicting notions of truth and power. According to the French philosopher, Michel Foucault, sociopolitical power creates truth. This "power reality" is embodied in the play by Prime Minister Kageyama, and its authority is challenged by his wife, Asako, who has an entirely different conception of truth. This interplay of conflicting values has helped to maintain the popularity and stature of the play for half a century.
\end{abstract}


My family and grandparents 


\section{Acknowledgements}

This thesis owes much of its value to my advisor Dr. Laurence Kominz, not only for the help and advice he gave me in critiquing, commenting and editing, but for the encouragement for me to complete it. I am grateful to him for what he has taught me and for the interest he has stirred in me in writing critical analyses and exploring Mishima Yukio's life and his plays.

Additionally, this thesis could not have been written without the love, emotional support and encouragement of my family and several of my friends. In particular, a special thanks to Robert Hegwood, who spent many hours reading, editing, and offering me feedback on my thesis. Without his support, I would not be able to complete my studies. Also, I want to thank Amanda Radmacher, Muath Alissa, all of my graduate studies' colleagues and so many others who have contributed to my completion of this work. I offer to all of you, my most sincere appreciation. 
Table of Contents

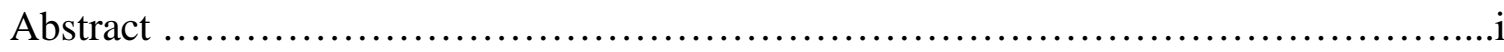

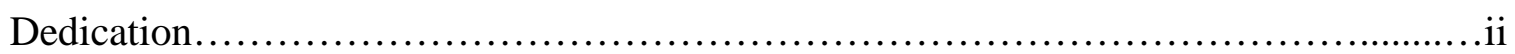

Acknowledgements.............................................................

Author's Note...............................................................

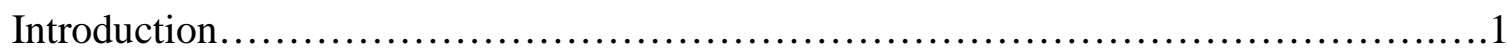

Mishima and Drama................................................................

Production History of Rokumeikan...........................................6

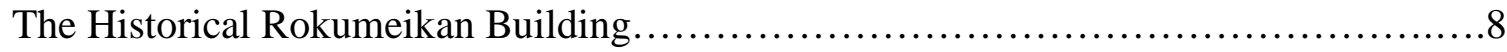

Rokumeikan Plot Summary....................................................11

Characteristics of Rokumeikan .............................................. 15

Performers' insights and approaches to Rokumeikan: Sugimura Haruko, Mizutani Yaeko, and Nomura Reiko........................................................... 21

Critical Approaches to Rokumeikan: Japanese................................27

Critical Analysis Based on Western Literary Theory: Power, Truth and Sexuality in

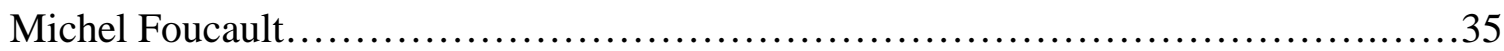

What Creates truth in Rokumeikan? Power or Love? ...............................42

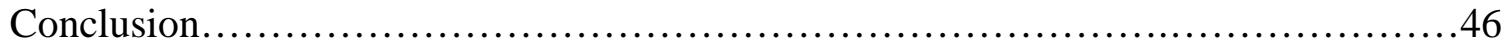

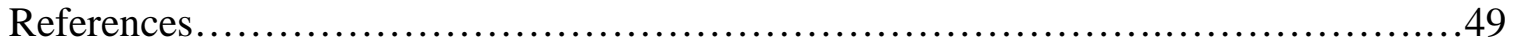

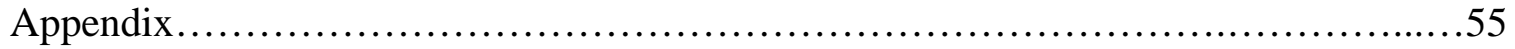


Kyûgeki is a broad term for classical Japanese-style drama, which includes kabuki, noh, and kyôgen.

The term shingeki ("new theater") was first used in 1924. Shimamura Hôgetsu and Osanai Kaoru developed this performing art form, in beginning 1906 (Meiji 39). In 1909 (Meiji 42), Ichikawa Sadanji II established Jiyû Gekijô theater, a prototype for shingeki. Shingeki is Japan's version of modern, psychological realist drama (Kominz, 2007). This style was first used to perform translated works of Western plays written by Henrik Ibsen, Anton Chekov, and other playwrights, and from the 1920s, Japanese playwrights began to write shingeki plays. Shingeki centers on modern people's lives. Elements include Western clothes and self-contained plots. After WWII, Uno Jkûichi and Sugimura Haruko were the most important performers of shingeki plays. Shingeki troops still produce many plays and talented performers.

Shimpa was derived from agitation Propaganda Theater promoted by the Liberal Party in 1880s. After 1900, shimpa included many romantic, spectacular plays. Compared to kabuki, it is more contemporary and realistic. Shimpa's melodramatic stories are presented in a traditional, historic, Japanese style, broader than shingeki plays. Works by novelist-playwrights like Izumi Kyôka, and Ozaki Koyô are good examples of this style. Until the retirement of leading performers such as Hanayagi Shôtaro and Mizutani Yaeko in1980s, shimpa was very successful, but shimpa still performed today. 
Introduction

Mishima Yukio was a famous Japanese novelist as well as a playwright. Mishima gained acclaim as a writer from an early age. At the age of nineteen (1944), Mishima published his first short novel, Hanazakari no mori (The Forest in Full Bloom), and at the age of twenty four (1949), he made his professional debut as a playwright with Kataku (the burning house) (Mishima Yukio Literary Museum, 2007). As a dramatist, Mishima wrote more than sixty plays before his death in 1970, and nearly all of them were staged in his lifetime (Sato, 2002). "Mishima wrote plays in a wide range of genres: straight drama, kabuki, dance drama, screenplays, musical drama, radio drama, and opera libretti. The vast majority of them were Japan's modern, realist stage (shingeki) and for kabuki (Kominz, 2007, p.1).” During the 1950s and 1960s, his popularity with audiences was at its apex (Kominz, 2007). Even though Mishima wrote many masterpiece plays, he has been widely known more for his novels. Kominz (2007) believes this is because "many of his plays have not been translated into English and Mishima's non-Japanese biographers have shown little concern for his work in theatre (p.1)."

For Mishima, plays were the closest to his heart. In Ratai to Ishô (Naked and Costumed), Mishima wrote, "above all else I adore the drama, and I love the theaters in which they take place. ...Writing novels is contemplative, analytical work requiring perseverance, but writing plays is different. Drama stirs the emotions. I can never separate myself for long from the frenzy and the passion of the theater (Mishima, 1959, p.133)." He loved the theater so much that he often gave himself walk-on roles. For instance, he appeared in Britannicus (1957), Koi no hokage (Sails of Love) (1964), 
Arabian Night (1966), and Kurotokage (Black Lizard) (1968) (M. Kudo, personal communication, February 23, 2010). In 1956, he appeared on stage as a carpenter in Rokumeikan (Mishima Yukio Literary Museum, 2007).

Mishima committed suicide in 1970, but even after fifty years, his best works still maintain widespread popularity both inside and outside of Japan. For example, Madame de Sade (Mishima, 1965), translated into English by Donald Keene in 1967, was performed in Wyndham's Theatre in London, 2009, and Rokumeikan was performed in Jiyû Gekijô in Tokyo, 2009. An opera version was performed in $24^{\text {th }}-27^{\text {th }}$ June, 2010, and tickets were sold out two months in advance. His modern noh plays are "the most frequently performed Japanese plays around the world (Kominz, 2007, p.16).”

In this paper, I will examine Rokumeikan in the context of Mishima's dramatic career, and the circumstances of its writing and production. An analysis of Mishima Yukio's multi-play opus reveals why Rokumeikan is his supreme achievement for the Japanese stage. In previous critiques, scholars and drama critics analyzed Rokumeikan from many perspectives; however, their analyses did not fully express why this play remains a big hit in Japan. I will investigate the popularity of this drama by examining literary criticism by scholars and critics, from the performance notes by directors and actresses, and by employing the critical theory of Western philosopher, Michel Foucault, who provides insight into political power and truth. In addition to Michel Foucault's philosophy of power and truth, I will analyze Rokumeikan using the Japanese concept of giri (duty one's personal superiors) and ninjô (feelings of love and affection). In a world in which social obligations and personal desires conflict, and in which social and political power 
constrain individual freedom, love can still encourage a person to risk everything. Love can be a source of power to challenge absolute political power in society.

Eventually, it is more than just the text of this play that makes Rokumeikan the most successful shingeki play in post war Japan. A physical embodiment of the struggle of emotion against political power is a crucial feature of this play. Conflicting human sources of truth and reality are at the foundation of the play's appeal. 


\section{Mishima and Drama}

The time of Mishima's adolescence was in the midst of the war. The future was very uncertain and he could not make educational and career plans freely (Okuno, 1956). During the war, people had an idea that the war would determine one's fate (Okuno, 1956). Most importantly, experiencing World War II affected Mishima's writing because the war demonstrated the intrinsic relationship between power and truth.

Losing World War II invited the collapse of social authority in Japan. The end of WWII brought "the psychological disintegration, the collapse of superego "conscience," and failure of the binding force of morality" to the people who lived through this war (Okuno, 1956, p.53).”

The time in which Mishima lived in adolescent to adult was "an era when unquestioned authorities collapsed and values were distorted (Okuno, 1993, p. 18)." Without Japanese political and social power, truth was difficult to perceive. The truth promulgated by the powerful U.S. authorities seemed artificial. "Mishima experienced the war in his youth and after suffering from war time window-dressing morality, he understood the debacle of ready-made morals. From this situation, he understood that morals are just a policy which is created by the central government (Okuno, 1993, p.60)." Recognizing this fact, Mishima problematized morals in almost all of his plays, including Rokumeikan. Noguchi Takehiko (1968) described Mishima as "a person who could not adapt to daily life after the war (p.222)." Noguchi (1968) considers that Mishima had a 
mixed reaction to Japan's suddenly overturned power and truth, and had a feeling of abandonment.

In Ratai to Ishô (Naked and Costumed), Mishima states that "The tendency to disdain formal structure in life coupled with the tendency to respect only facts actually leads most people to allow fantasy and imagination into the world of factual knowledge. The common political ethos, especially the conviction that democracy is the right thing for all of the people, leads to a dangerous spread of "wishful factuality." The masses don't like naked truth. If confronted before their eyes with both an attractive lie and an ugly truth they will always choose the attractive lie. Knowledge of this is politicians' most important weapon...and it is the basis of all idealistic political theories and discourse (Mishima, 1959, p.197, L. Kominz tr., personal communication, July 21, 2010).”

Mishima's way of viewing truths derives from his war experience and it affects his writing. For example, in Rokumeikan, the historic building itself is an emblem of the empty truth. "Beautiful buildings and masked characters represent various beautified ugly truths, but Mishima makes it clear that there is no absolute truth. By presenting truths from different perspectives Mishima created a world full of complicated human emotions and competing social values. 


\section{Production History of Rokumeikan}

Rokumeikan is "a post war play which is widely perceived to be a Japanese masterpiece (Okuno, 1993, p.268)." Mishima wrote Rokumeikan in 1956, when he was thirty one (Honda, 1970). Bungaku-za (Literary Theater) commissioned Mishima to write this drama to mark the theater troupe's twentieth anniversary. Mishima said that he wrote this play as: "work to showcase actors and acting (Mishima, 1956 b)." Mishima intended the lead role for Sugimura Haruko (Honda, 1970), the marquee actress of the Bungaku-za (Literary Theater). Rokumeikan was first performed at Daiichi Seimei Hall from $27^{\text {th }}$ November to $9^{\text {th }}$ December in 1956 . Following this production Rokumeikan toured thirty seven cities within three years. After publishing Rokumeikan in December 1957 in the monthly Bungakukai (The Literary World), Mishima received lavish praise from the literary world for the play's use of “classic style in a modem setting (Honda, 1970, p.289)." Rokumeikan firmly established Mishima's fame and stature as one of the leading playwrights in Japan (Honda, 1970). The play continues to be shown frequently to the present day (see appendix). From 2006 to 2009, Rokumeikan was performed more than 200 times at the Jiyû Gekijô, and more than 96,000 audience members came to view this play (Rokumeikan ni tsuite, 2009) at this theater alone. Most recently at Jiyû Gekijô from $14^{\text {th }}$ September to $10^{\text {th }}$ October in 2009 , Rokumeikan was produced by the Shiki Theatre Company, the leading commercial theatre production company in Japan Shiki Theatre Company, 2009 a). This run of the play commemorated the $100^{\text {th }}$ anniversary of shingeki (the western style drama) in Japan. Asari Keita, the leader as well as the Artistic Director of Shiki Theatre Company said, "A play is the art of language. Performance takes that 
language and makes it into a three dimensional creation. On this $100^{\text {th }}$ anniversary of shingeki, I chose this play because of its significant literary value (Takahashi, 2009)."

Rokumeikan is a literary masterpiece that is also beloved by audiences. To meet fans' requests, the performance DVD was released March $26^{\text {th }}, 2010$ (Shiki Theatre Company, 2010 c). Furthermore, Rokumeikan was adapted as an Opera performance by the New National Theatre, which is a great honor for the play. The opera version of Rokumeikan was presented from $24^{\text {th }}$ to $27^{\text {th }}$ June, 2010 at the New National Theatre, Tokyo (The National Theatre of Japan, 2009). 
The Historical Rokumeikan Building

In Japan, Rokumeikan was the name of a historical building before it was a play. Rokumeikan (meaning "Deer Cry Pavilion" in Japanese) was built in Tokyo and then used by the Japanese government from 1883 to 1893 . Rokumeikan was "a large ornate Western-style brick building, with sitting rooms and a spacious, open ballroom on the second floor (Kominz, 2007, p.30)." Rokumeikan was an architectural symbol of the Meiji government policy popularly known as bunmei kaika (1868), “civilization and enlightenment (Sato, 2002)," a policy that advocated modernization. The term Bunmei kaika came to signify the mid Meiji period when Japan started to emerge from its isolation period and haltingly began to join the fold of the international community (Dômoto, 1994). Meiji's leading politician, Inoue Kowashi, believed that foreign policy difficulties were caused by the Western industrial countries' view of Japanese customs as barbaric: he therefore sought to improve relations by transforming customs and public morals (Naramoto, 1956). As part of the effort to revise the unequal treaties with European countries and America, Japan undertook a number of policies of Europeanization. The government's purpose was to project a favorable image of civilized Japan to the West to encourage cooperative relations on an equal footing (Yamaguchi, 1988). Rokumeikan was a British-designed Renaissance-style social center built as a place where the Japanese upper classes entertained foreign dignitaries (Asukai, 1992). Unfortunately, in 1893, an earthquake damaged the building, and due to the enormous cost, the government could not afford to repair it (Sato, 2002). Nevertheless, the building was used as a social club for Japan's aristocracy until 1933. Sato writes that, "The ball on 
the night of November 3,1886, on which Mishima bases this play, was a grand affair. Seventeen hundred guests attended the gala, which was hosted by the foreign minister Count Inoue Kaoru (1835-1915) and his wife (Sato, 2002, p.1).” In Rokumeikan, Mishima uses this gathering at the Rokumeikan building as the setting; however, the play's story and the real historical event have no connection.

Mishima loved making paradoxical statements in his work. In this play, Mishima used the gorgeous Rokumeikan building as a setting to display a world of dazzling beauty. He transposed that image against the image of ugly human relationships among the gorgeously dressed guests at the ball. This paradox challenges the way the audience sees the Rokumeikan building. Mishima compared the shining facade with the ugly side of human nature-betrayal, hatred, lying, and deception. This paradoxical situation is a driving force in the plot of his play. Mishima also attempted to create a different narrative of the events that took place at the Rokumeikan, opposing to contemporary negative views of the history of the building. Most Japanese consider Rokumeikan period to have been a waste of government at a time when Japan had more pressing needs. Mishima believed that this position did not account for the views of the aristocrats who used the Rokumeikan. It is possible that aristocrats in Meiji era considered the events at the Rokumeikan a positive development for Japan. Mishima believed providing opposing interpretations to contemporary normative views of history is a writer's job (Mishima, 1962). "The key to the success or failure of this play depended on how successfully Mishima could transfer the significance of the central players' actions at Rokumeikan into the realm of universal emotions (Dômoto, 1994, p.258).” Donald Keene (1988) 
believes that Mishima's intention of writing Rokumeikan was to depict his idea of genuine Japanese people as opposed to modern "Westernized" Japanese people (Keene, 1988, p.20, author's tr.). Instead of writing about Japan's humiliating racial political subordination in the Meiji era, such as the failure to recover tariff autonomy and to abolish extraterritorial jurisdiction by foreign countries, Mishima wrote Rokumeikan to change Japanese views of the Meiji period. Mishima wrote, "In the 'Rokumeikan period', both senryu (Satirical haiku) and nishikie (Color print) described this time as a truly ridiculous and grotesque period; as if it were a parody of civilization. However, in my play, I wrote about my grandfather's time as a gorgeous, romantic time, rich with nostalgia. I portrayed it as one of the greatest periods in modern Japanese era (Mishima, 1967)." According to Sato, Mishima said, “During the ball on the Emperor's Birthday, on November 3 of the nineteenth year of Meiji, nothing remotely resembling the incident seen here [in the play] happened. However, the flaw of history is that it is written is about things that happened, but not about things that did not. That's the crack through which novelists, playwrights, poets and other frauds slip in (Mishima, 1956 b, p.5 in Sato, tr., 2002, p.2)." History tells the present generation what occurred, but does not tell what did not occur; therefore, writers can freely use their imaginations to create fictional plays to convey alternative historical events. Mishima's alteration of history in Rokumeikan creates a new imaginary space, where audience members can re-evaluate their view of Meiji history. The difference between history and Mishima's original dramatic action commands the audience's attention and creates excitement in the theater. 


\section{Rokumeikan Plot Summary}

The play Rokumeikan is divided into four acts.

The first act is set in the tea room, called Senkantei at Count Kageyama's residence. It is eleven o'clock November third in 1886, the Meiji Emperor's birthday, and a military review is being held. Wives of an army general, a baron, and a nobleman gather in the tea room, and they are peeping at their husbands through a telescope. The wives are discussing Count Kageyama's wife, why she does not attend either the emperor's congratulatory palace visit or the evening party held at Rokumeikan Hall. Every year on this day the Prime Minister, Count Kageyama, hosts an evening party at Rokumeikan. Count Kageyama's wife, Asako, used to be a famous geisha in Shimbashi. The other noble wives have started to wear Western clothes, but Asako never wears Western clothes in front of others and she always wears kimono, preferring the traditional style. It was her policy not to get involved in politics, which meant not attending the evening party at Rokumeikan Hall. After a while, Count Kageyama's wife Asako comes into the room and the Marchioness Daitokuji Sueko and her daughter Akiko consult with Asako regarding Akiko's romantic complications with Hisao Kiyohara. Hisao is the son of Einosuke Kiyohara, who is the leader of the Liberal Party (Jiyû Party), the leading opposition party. Unknown to the ladies or to Hisao, Asako is Hisao's mother. Einosuke takes a different position from the main party, opposing the Westernization efforts symbolized by the Rokumeikan Hall. Countess Sueko and Akiko want Asako to help with Akiko and Hisao's courtship. When Asako hears Akiko's lover's name, she is surprised because Hisao is her son. After the ladies leave Hisao appears, and Asako and 
Hisao meet each other for the first time in more than ten years. While they are talking, Hisao refers to the grudge he has against his father, Einosuke, and also to the agony of not knowing his own mother for his entire life. Hisao holds a grudge against his father because he is committed so fully to his political career. This left Hisao at the mercy of the maids who neglected him and made him sleep in the kitchen. Einosuke's neglect led Hisao to believe his father was deliberately treating him miserably. But Einosuke did not know how Hisao was spending his childhood. Hisao thinks that his father never loved him. After hearing Hisao's agony and yearning for his real mother, Asako decides to tell Hisao the secret which she has kept in her heart for long time, namely that Hisao is her real son, and his father Einosuke Kiyohara and Asako used to love each other when Asako was a young geisha. The story of Countess Sueko leads Asako to think that Hisao might be planning to kill her husband, Count Kageyama. However, Asako recognizes that Hisao plans to murder Einosuke, his father, when Einosuke's followers intrude into the Rokumeikan that evening. Above all, Hisao despises idealism. By killing Einosuke, Hisao declares that he will die not for a political cause but for personal sentiment. Hisao's plan to kill his father is an attempt to gain his father's recognition with a display of courage and fortitude.

The second act takes place in the same Senkantei tea room, but around one o'clock in the afternoon. Asako asks Einosuke Kiyohara to come to Count Kageyama's residence while he is out and they meet each other after a hiatus of twenty years. Asako and Einosuke reaffirm their feelings of love toward each other. From the talk, Asako hears Einosuke's regret for not taking good care of his son, Hisao, but Einosuke 
nonetheless loves his son very much. Soon after, Asako pleads for Einosuke to call off today's intrusion into the Rokumeikan. Einosuke does not want to change his plans. However, when he hears that Asako will attend the evening party for the first time, Einosuke promises Asako that he will call off the intrusion. When Count Kageyama comes back to the residence, Einosuke leaves without being noticed. Her husband starts to discuss something with Tobita, his confidant, in the Senkantei tea room. Asako and Kusano, the head maid, are listening to what they are discussing from their position, hiding behind a tree. Asako recognizes that her husband is conspiring to kill Einosuke. Count Kageyama and Hisao met about a month before when the Count Kageyama recognized that Hisao was harboring hatred against his father. Using Hisao's feeling, Count Kageyama tries to make the assassination seem like a family squabble between father and son, and not an assassination planned by him. After listening to their murderous plot and contemplating for a moment, Asako appears in the tea room and tells her husband that there will not be an intrusion by Einosuke's followers at the Rokumeikan building tonight. She tells Count Kageyama that she has decided to attend tonight's evening party at the Rokumeikan. Count Kageyama tries to find out the reasons for Asako's sudden willingness to attend, but she refuses to provide any information. Therefore, he decides to coax Kusano, the maid, to tell him the truth.

The third act takes place at the Grand Ballroom in the Rokumeikan, the same day, around four in the afternoon, just before sunset while people are beginning preparations for the evening party. We see Hisao and Akiko in the hall. After talking with his real mother, Asako, Hisao is calmed and feels better. Hisao has started to trust people and his intention to kill Einosuke faded away. Meanwhile, Count Kageyama easily coaxes the 
truth out of Kusano. He discovers the relationship between Einosuke, Hisao and Asako. Count Kageyama decides to carry out the assassination plot against Einosuke Kiyohara by any means. When Count Kageyama finds Hisao, he says that he lost respect for Hisao because he decided not to kill Einosuke and then tries to make Hisao angry by berating him. After getting Hisao worked up and in a deadly mood, the Count hands Hisao a pistol. The evening party is just about to begin.

The fourth act is also set at the Rokumeikan Hall, the same day, after nine p.m. There are various members of the Japanese elite and foreign dignitaries appear in the hall and people are greeting each other. After awhile, Asako hears from a servant that Einosuke's followers have intruded into Rokumeikan. To keep them from interrupting the party, Asako tries to prevent them from coming up to the ballroom on second floor, even at the risk of losing her life. By seeing this, Hisao believes that his father betrayed him and Asako, and Hisao goes outside of Rokumeikan. After awhile, everybody hears two gun shots from outside of the Rokumeikan Hall. Asako is told that Hisao has been killed. When Asako finds Einosuke, shouts and insult at him, he tells her that the people who intruded were not his followers and says that Hisao wanted to be killed by him, his own father. Einosuke kept the promise which he made to Asako not to intrude into the hall. When she hears the entire truth, she can no longer believe Count Kageyama and she tells him that she will leave Count Kageyama for Einosuke. Einosuke leaves Rokumeikan and soon after that both Asako and Count Kageyama hear a gun shot from outside of the Rokumeikan. The curtain closes after this mysterious gunshot. 


\section{Characteristics of Rokumeikan}

It is important to note that the imaginary space of Rokumeikan is not necessarily a pleasant place. Rokumeikan is a tragic drama which exposes the dark side of human beings, their acts of deception and betrayal, all with the backdrop of the beautiful Rokumeikan building. In 1962, Mishima wrote an essay about his play Black Lizard, and his analysis of it applies to Rokumeikan as well: "The play should be a thing with substance. There should be the feeling that behind eight hundred lies, a shining truth can be seen (Mishima, Kominz tr., 2007, p.242-243)." Rokumeikan is a complicated fictional drama, replete with swirling conspiracies, insidious behavior, and desperate love.

One reason for popularity of Rokumeikan is Mishima's use of classical elements in the shingeki (modern) format. "Shingeki playwrights rejected the classical language of kabuki and strove to use the language of everyday speech in their texts (Kominz, 2007, p.4)." However, Mishima used the aristocratic language of the Taishô era for the dialogues in Rokumeikan. Isoda Kôichi (1967) pointed out that Rokumeikan utilized classical kabuki style character elements. In Rokumeikan characters behave in traditional manners: restraining their emotions rather than displaying them, favoring ideals over reality, and ordered manners rather than freedom (Isoda, 1967). Nevertheless, as in Kabuki, characters' feelings are fully known to the audience. Rokumeikan characters behave more like kabuki characters than shingeki characters. The characters' ways of portraying thoughts and feelings are like kabuki in that the main female character, Asako, hides her feelings from her husband, but makes them clearly known to the audience. Kabuki also relies on beauty and splendor and a distinctive presentational style. 
About Rokumeikan, Mishima wrote, "what calls the audience out of the existing daily emotions in which it sleeps should indeed be the style of the play (Mishima, Sato tr, 2002, p.59)." "Most Japanese thought of shingeki as realistic theatre, but Mishima saw shingeki acting as no less pattern-bound than kabuki or noh acting (Kominz, 2007, p.31)." "The key to success, Mishima believed was to fill the patterned acting with intense, psychologically believable emotion (Sato, 2002, p.58)."

Stage conventions also contain classical elements. Okuno (1956) commented that Rokumeikan employed several kabuki elements. At points of high tension, the play makes use of sound effects to punctuate the importance of events, such as when cannon shots are heard. Asako confesses her real feelings and her son Hisao declares the target of the murder is his father. Kabuki also uses sound effects to enhance scene of action and high emotion (Japan Arts Council, 2007). Isoda writes that in Rokumeikan, Mishima uses the kabuki shared-line style of dialogue (wari zerifu), where two characters speak in succession to complete the same thought, or even the same sentence, finishing the thought by speaking in unison. Different from typical shingeki plays, Mishima controlled the performers coming and going in an extremely choreographed manner, as the writer/director does in kabuki. The integration of modern and classical conventions makes this drama very distinctive.

Additionally, Rokumeikan has been well accepted among viewers because of its fascinating characters, their complex relationships, the play's intricate plot lines, and rich stage settings. 
Firstly, the characters in Rokumeikan attract the audience through their complexity. The heroine, Asako, has an intriguing personality. She has characteristics which are both similar to and different from ordinary women. She possesses beauty and money which puts her above most women, but, she is a good-hearted person with a difficult family situation, which allows women in the audience to feel empathy for her. Audiences admire and sympathize with Asako. As for other characters in the play, the action of antagonist, Einosuke Kiyohara, provides dramatic tension and suspense. Einosuke Kiyohara, Asako's previous lover and now a leader of the Liberal Party, is the main opposition leader, challenging the policies of Asako's husband, Prime Minister Count Kageyama. Asako is positioned between the two political foes and tragedy occurs. This is one source of her personal conflict. The tragedy of the play originates in Count Kageyama's conspiracy to murder Einosuke Kiyohara, to relieve his jealousy and improve his political situation. Count Kageyama manipulates the tragic action, inducing Einosuke Kiyohara and Hisao (Einosuke and Asako's son), to carry out acts of violence (Honda, 1970). Conflicts among characters are caused by a tension between the opposing familial and political duty (giri) and spontaneous emotional attachments (ninjô). For example, Asako has familial duty to Count Kageyama as his wife. Contrasted to Count Kageyama, Asako has feelings of affection (ninjô) for Kiyohara and Hisao. Asako loves Kiyohara as a former lover, and she feels compassion and love for Hisao as his mother, even though this relationship is kept secret from society at large. Her mixed emotions provide dynamism in Rokumeikan. 
Secondly, unpredictable twists in the plot make this play fascinating. For example, Rokumeikan is the emblem of a spectacularly flamboyant world, and represents success and prosperity. But in reality, the inside of this building is filled with false displays, deception, and lies. The building and the people in this building embody a nihilistic world. Rokumeikan presents a huge gap between outer appearance and inner reality which defies the expectations of the audience. The surprising story line mesmerizes its viewers. The power of Mishima's writing lies in his usage of contrasting expressions in this play.

Thirdly, Mishima's Rokumeikan epitomizes fine dramatic craftsmanship. As Okuno (1993) mentions, it includes luxurious atmosphere, catharsis, a Western-style dress up party, young men's political movement drama, family drama, politics and love, conflict between love and duty, and beautiful verbal expressions which were used in Taishô era (1912-1926). Mishima employed upper class language current in Tokyo during the Taishô era for his dialogue in many novels and plays. Okuno (1993) stated that this was because Mishima was proud of the upper-class Yamanote, Tokyo language style. Mishima pursues both linguistic and aesthetic beauty in this work.

Lastly, Rokumeikan came into the spotlight because it included elements which were not seen in earlier modern plays (Honda, 1970). In modern plays (Gendaigeki), the stories are set after the restoration of Imperial power in 1868. The drama Rokumeikan is set in 1886 and this makes it a modern play. Even though the play is set in the modern era, some characters, including the heroine Asako, maintain archaic attitudes. Asako is portrayed as an old-fashioned lady, considered to be somewhat antiquated by the women 
of the Meiji era. According to Setouchi Harumi (1967), the Meiji era was a time when women's right movements were born and began to spread. Nevertheless, most women still adhered to the traditional family system because they felt compelled to obey and serve the family (Setouchi, 1967). For most women in the Meiji era, experiencing romance and falling in love were uncommon (Setouchi, 1967). However, geisha existed in a different realm, separate from both the women who were ahead of their time and women who went with the flow of Meiji society. In the world of geisha, it was acceptable to silently hire their favorite actor for pleasure, or to have a lover besides her patron (Setouchi, 1967). Before marrying Count Kageyama, Asako was a geisha. Setouchi explained setting Asako's character as a former geisha was indispensable to make her experience believable within the social order of the Meiji Era (Setouchi, 1967). Being a former geisha, Asako feels comfortable in traditional kimono and she has the reserved character typical of geisha. Because of her humble origins, she feels uncomfortable among her new female peers once she is married. Typical of geisha, she keeps her feelings behind a mask that she shows to the public in order to protect herself. Asako had prestige in her geisha society, but in the outer world, her power and status is dependent upon marriage to a man with a high rank in society. Unlike women of the upper class, Asako chose not to adopt the Western style dress of the women in Count Kageyama's social circle. She says that she doesn't want to "ape" Western customs. But she also knows that aristocratic ladies will accuse her of "putting on airs" if she wears Western clothes. Rokumeikan was a place for Japanese aristocrats to entertain foreign dignitaries. The adaptation of Euro-centric manners was supposed to be an upper class endeavor. As the wife of Count Kageyama, Asako has the right to attend events at Rokumeikan, 
however; she is not originally from a noble family. This dilemma causes Asako to stay in her shell prior to the events of this play. Maintaining traditional dress and demeanor is a way to prevent controversy. Asako's old-fashioned behavior in the modern setting of Rokumeikan also adds an element of surprise that stirs up the audience. She wears a Western dress in public for the first time when she attends the ball in act three.

Rokumeikan continues to maintain its popularity thanks to its attractive and sympathetic heroine, its exotic and nostalgic setting, the complicated relationships among characters, and unexpected twists in the plot. Furthermore, Mishima's rich, artistic craftsmanship, including his beautiful language usage, incorporation of Japanese and Western aesthetics in the stage setting and costumes, and inclusion of traditional Japanese values in conflict, ninjô (love) versus giri (obligations), make the play fast moving and enjoyable. 
Performers' Insights and Approaches to Rokumeikan: Sugimura Haruko, Mizutani Yaeko, and Nomura Reiko

Among Mishima's plays, Rokumeikan is renowned for its dramatic intensity and has been especially popular among actresses who played the lead role of Asako (Dômoto, 1994).

For Sugimura Haruko, the leader of the Bungaku-za theatrical company in 1956, Rokumeikan stood out in her memory. She would never forget this magnificent play (Sugimura, 1959). Sugimura considered Rokumeikan an enjoyable play which brought suspense to the boiling point.

The performance of Rokumeikan in 1956 marked the important twentieth anniversary of Bungaku-za's founding. In Tokyo, tickets sales were in great demand and Bungaku-za decided to add two more matinees after the first two days of advanced sales. Rokumeikan was widely successful and within three years (1956-1959), Bungaku-za did nearly eighty performances all over Japan. All of the members in Bungaku-za had a role in Rokumeikan and this drama was particularly memorable for the whole troop (Sugimura, 1959).

In Sugimura's essay, she wrote her appreciation of Mishima. Sugimura felt grateful to Mishima that he wrote Asako's character as the heroine with her in mind (Sugimura, 1959). She declared that "it is impossible to describe in words how pleased, excited, and overjoyed I was (Sugimura, 1959, p.206).” This was her dream role and she was thrilled performing Asako (Sugimura, 1959). 
Sugimura mentioned the beautiful aesthetic qualities of Mishima's style and fascinating dialogue in Rokumeikan. Sugimura praised Mishima's writing style which contained many rhetorical flourishes. Mishima's style of writing had an appeal compared to other plays which were more prosaic. To the shingeki performers who were used to realistic drama, Mishima's focus on the beauty of dialogue and writing style was innovative. Sugimura recognized, "New theatrical performance and new performers will come into the world only from the new writing styles (Sugimura, 1959, p. 207)." For her first performance of Asako in 1956, Mishima gave Sugimura important advice. Rokumeikan "was a grand historical melodrama, and Mishima believed it had to be presented in a grandiose, historical style. It was shingeki, but in the spirit of shimpa (Ôzasa, 1995, p.193)." Mishima told Sugimura "Do the part however you want, but make it big. People have said that your acting is too much like shimpa, but that's exactly right for Rokumeikan. It's not a play, it's DRAMA. Do it with big, dramatic postures (Ôzasa, 1995, p.193)." "Mishima had secured the actress he thought best for the Asako role, as well as the director he wanted for the play, Matsuura Takeo (1926-1998), who would be directing his first Mishima play (Kominz, 2007, p.31)."

Rokumeikan meant a lot to other performers as well. Shimpa's greatest leading actress Mizutani Yaeko (1905-1979) and Gekidan Shiki's well-known performer Nomura Reiko (1961-) also performed Rokumeikan for the first time in 1962 and 2006 respectively. Rokumeikan was one of Mizutani's favorite plays. She included Rokumeikan among the last ten plays she would perform. Although Nomura Reiko did 
not express particular fondness for Rokumeikan as a leading actress in the Shiki Theatre Company, she demonstrated her acting skill when performing Asako in Rokumeikan.

No visual recordings exist of Sugimura Haruko and Mizutani Yaeko's performances, but I was fortunately able to listen to the Mizutani Yaeko's Rokumeikan voice file and to watch Nomura Reiko's performance in person in September, 2009.

The performances are distinguished by different approaches to acting the character of Asako. Each performer used quite different vocal demeanor. In 1962, Mizutani Yaeko performed Asako for her first time. She was the leading shimpa actress of the $20^{\text {th }}$ century, so her style was much grander than any shingeki actress. Mishima envisioned his play differently than he had in 1956. Mishima wrote in a play program if the tension of dialogues is released entirely, this drama becomes just a tear-jerker. (Mishima, 1962). Mizutani Yaeko's voice was strong, dynamic, rhythmical, and melodic. She maintained the high level of tension that Mishima sought in this production. On the other hand, in 2009 Nomura Reiko's voice was clear, with a detached, even tone. One reason for the vocal difference is Nomura's Shiki-method (Sankei News, 2009). This method uses clearly pronounced vowels and that allows the audience to hear dialogue clearly (Sankei News, 2009), but the overt focus on vocal technique suppresses the expression of emotions by characters. Nomura's performance was less expressive and more emotionally contained. As a result, Nomura's performance held the beauty of a still-life portrait, but it failed to elicit a strong emotional response by the audience. Asako's costumes in this play also supported a subdued interpretation: a dark purple- 
brown kimono in Act One and Two and a dark purple and grey gown in the Rokumeikan scenes.

Different presentation styles are partly due to the difference between the forms of performance. For instance, both Sugimura and Nomura are shingeki actresses, while Mizutani belonged to shimpa. Shimpa is closer to kabuki, and thus Mizutani's performance was rather emotional. When Asako was confronting Count Kageyama in the last act, Mizutani used a sorrowful staccato within dynamic speech to convey emotional swings to the audience: Asako's deep sorrow, disappointment, and fury. Mizutani captured the essence of Asako's tragic life in a nihilistic world. In the same scene, Nomura vocalized the dialogues strongly, however; the tone and rhythm of her utterances did not change very much even though she was expressing very different emotions. Nomura presented Asako as a sentimental, weak, but unruffled person. Nomura's Asako was more of a mother who worries about her son's possible impending death whereas Mizutani's Asako was a heroine in the midst of a grand tragedy. I was unable to observe Sugimura Haruko's performance because her last performance was before I was born and no video record exists of her Asako, but as she belongs to shingeki, Nomura's performance was likely closer to Sugimura's vocal style.

Although they are both shingeki actresses, Sugimura and Nomura appeared to have different approaches. The drama critic Endo Shingo (1958) observed Sugimura's Rokumeikan and he wrote that Sugimura's acting was closer to the kabuki style. Endo explains that Sugimura used a kabuki technique to express sentiment and deep feeling (Endo, 1958). Like kabuki performers, Sugimura acted and vocalized using different timing from shingeki (Endo, 1958). In 1956, Rokumeikan director, Matsuura Takeo 
recognized the play's classical Japanese theatrical elements (Matsuura, 1956), and his understanding of this play of course influenced Sugimura's performance. On the other hand, Asari Keita who directed the 2006 and 2009 productions was most impressed by the play's classical Western elements. He therefore directed Nomura not to use kabuki like technique, and she used Western theatrical play technique. In the play, Nomura allowed her words and emotions to create physical movement, unlike kabuki acting in which both words and actions are carefully calculated. In this, Nomura was different from Sugimura and Mizutani, and her Asako was less grand.

Each actress used her own, unique approaches to perform Asako. Mizutani’s performance was particularly impressive and even inspirational. Sugimura and Nomura's performances focused more on the beauty of the dialogues. Like Sugimura, Nomura was very concerned how to speak as Asako: "I think to produce dialogues in melodic style is dangerous (Nomura, 2009)."

Reflecting on the performers' vocal demeanors and actions, Sugimura included kabuki elements in her play, but at the same time was very careful about delivering lines just as Mishima intended. Sugimura's performance met Mishima's objectives in Rokumeikan.

Despite the fact that Sugimura Haruko loved the play Rokumeikan and enjoyed the challenge of the Asako role, Sugimura and her company, Bungaku-za never performed this play after 1963. Mishima quit the company in November, 1963 when Sugimura Haruko, in her capacity of Artistic Director, cancelled his play Yorokobi no koto (The Harp of Joy) in the middle of rehearsals (Kominz, 2007, p.40). The left-leaning actors in the play refused to perform the play and Sugimura sided with them. Mishima 
quit the company and soon afterwards created his own new theatre company: NLT (New Literary Theatre). "Mishima did not leave Bungaku-za by himself. Thirteen other actors and directors followed him, including his close friend, and favorite director, Matsuura Takeo (Kominz, 2007, p.41)." From that moment, Sugimura proclaimed Mishima to be "her enemy" (Ôzasa, 1995, p.258) and as a company director, she prevented Bungaku-za from performing plays by Mishima for as long as she lived—until 1997. 


\section{Critical Approaches to Rokumeikan: Japanese}

Up until now, many scholars have analyzed Rokumeikan from various perspectives. Representative writers are on the topic include Setouchi (1967), Keene (1988), Honda (1970), Ikeda (1967), Tsujii (1988), Isoda (1967), Shibusawa (1967), Okuno (1958) and Dômoto (1994).

Setouchi Harumi (1967) analyzed Rokumeikan from a women's studies perspective to help her understand the women's rights movement in the Meiji period, as illuminated by Asako's personality and values. Around 1886 in the Meiji period, there was a growing women's rights movement, but it was largely suppressed by the government (Setouchi, 1967). Social activists in the "Freedom and People's Rights Movement," such as Kishida Toshiko (1863-1901) and Kageyama Hideko (1865-1927) wrote and spoke in favor equality of the sexes, but were often censored. Because of their radical theories and participation at the "Freedom and People's Right Movement", both Kishida and Kageyama were imprisoned in the late 1880s (Setouchi, 1967). In the play, Asako also seeks power, but in a different way. She uses the restrained ways of a traditional Japanese woman to seek personal power, as opposed to the women's rights movement and its public goals of suffrage, the right to divorce, and making women's voices heard at home and in society. According to Judith Butler, "To be female is, according to that distinction, a facticity which has no meaning, but to be a woman is to have become a woman, to compel the body to conform to an historical idea of 'woman', to induce her body to become a cultural sign, to materialize oneself in obedience to an historically delimited possibility (Butler, 1988, p.522).” As Butler (1998) states, gender, 
sex, and sexuality are socially constructed. Asako accepts this reality and follows the traditional expectations of an ideal woman. Acting as the "ideal woman" of 1886, Asako gained her power. To become an ideal woman in the Meiji period, Asako acts noble, remains shy, guards her inner feelings, cultivates a mysterious persona, remains private, wears kimono, and advocates traditional values. Despite claims of the women's rights movement that traditional women are submissive, Asako is a strong-minded woman. She not only attends the Rokumeikan party in an environment at odds with her traditional values, she even maneuvers against her husband's will in order to save the lives of her son and former lover. The women's rights movements confronted the Meiji government directly, but Asako chooses a non-confrontational solution. Knowledge of the historical woman's movement and story makes the drama more exciting and makes Asako seem more complex. Asako appears to be a traditional woman but she does not relinquish her own will. Unfortunately, the power Asako gains from her husband, Count Kageyama, is unstable because it is dependent on his stature and will. As a result, all of Asako's plans fail when he doesn't support them. This demonstrates the limitation of the social construction of gender in the Meiji period. Asako's attempt to solve her problems by maintaining traditional values is in contrast to women's actions in the women's movement, and this underscores Asako's character and adds meaning to Rokumeikan.

Keene (1988) used an intellectual and historical approach to comment on Rokumeikan in his article, "Rokumeikan jidai to Mishima Yukio (The Rokumeikan era and Mishima Yukio)". In this essay, he discussed the popularity of this play in Japan and overseas within the historical background of the Meiji era. According to Keene, the time 
of the Rokumeikan is nostalgic for Japanese people but was largely forgotten by foreigners, explaining why Rokumeikan is special for Japanese but not for non-Japanese (Keene, 1988). He also explored the reason why Mishima decided to write Rokumeikan. Keene comments that Mishima wrote Rokumeikan out of a feeling of reminiscence for the Meiji era (Keene, 1988). Mishima felt nostalgic about the Meiji period, the Rokumeikan building, and the plays which were popular during that time in Europe (Keene, 1988). During the $19^{\text {th }}$ century, "well-structured" (clear structure with straight ending) plays such as plays written by Henrik Ibsen (1828-1906) were popular at theaters in Europe (Keene, 1988). Keene (1988) thinks that Mishima had a fondness for the style of the plays at that time. He wrote Rokumeikan as a "well-structured play" to prove that this kind of play could still impress audiences in a time when modern plays often had vague structure and ambiguous endings.

In "Rokumeikan ron (the theory of Rokumeikan)," Honda Sôki (1970) focused on dramatic irony in the play. Honda claimed Rokumeikan was exceptional because of subtle and effective use of irony. Honda saw a deep irony in the play's conclusion. The play's main catastrophe occurs in an elegant and beautiful atmosphere that is the origin of the drama's rebellions and intrigues. Indirect approaches that Asako cultivates in order to protect her son and her former lover lead to their demise. This dramatic irony is also a major source of the play's catharsis.

Another reviewer, Yoshida Kenichi (in Honda (1970)’s “Rokumeikan ron”), shared many of Honda's views. Yoshida wrote that Asako's restrained manners brought on tragedy. The effort to retain a protective air of elegance was futile in the end. Around 
Asako, Count Kageyama transmits tragedy, and Hisao and Einosuke Kiyohara create disaster. Asako is the one who tries to prevent the tragedy, but, Asako is the one who invites the tragedy in the end. Honda believed that this dramatic irony was especially unique and makes Rokumeikan distinctive among Mishima's dramas. Honda (1970) considered the dramatic irony to be the main source of this drama's public appeal.

Ikeda Kotaro (1967) focused on exploring nihilism in Rokumeikan by comparing Count Kageyama to the Meiji era politician Yamagata Aritomo (1838-1922). In his essay, Ikeda found similarities in their personal ideologies. Yamagata Aritomo was born at the end of the Edo period (1603-1868) and was a Field Marshal in the Imperial Japanese Army and twice the Prime Minister of Japan. Yamagata Aritomo was known as the builder of the military and political foundations of modern Japan. According to Ikeda (1967), Count Kageyama and Yamagata Aritomo share three beliefs. Both of them value political cunning over ideology because they see the world as amoral, both prefer solitude because of a disdain for others, and both believe only in power. Ikeda described Yamagata Aritomo as a resolute person who discredited people and lived by the dictates of power and authority (Ikeda, 1967). Yamagata Aritomo's personality overlaps considerably with Count Kageyama's. In the story, Count Kageyama considers politics to be the province of the hypocritical because there is no absolute truth. For Count Kageyama, power is the only truth. In addition, Count Kageyama considers that trust between human beings is a fairy tale. Count Kageyama says, "Yes, I schemed and plotted. But the central point was to destroy for you the fairy tale that trust between human beings can be achieved (Mishima, Sato tr. P.52).” Ikeda wrote that Mishima's 
own political point of view was expressed by Count Kageyama. Finding similarities between Count Kageyama and Yamagata Aritomo, Ikeda considers Mishima to be a nihilist who held a pessimistic view of the workings of the human mind and heart. He believed every heart had an unknown, dark side. Ikeda mentions that Mishima and Yamagata Aritomo share the common idea that human beings are basically dangerous and evil creatures. Ikeda names Mishima the "Yamagata Aritomo of the Showa era" to explain Mishima's emotional attachment to the Meiji period and his nihilistic ideas which resemble those of Yamagata Aritomo. Finding connections among Mishima, Yamagata Aritomo, and Kegeyama, Ikeda analyzed the nihilistic world of Rokumeikan.

Drama Critic Tsujii Takashi (1988) also praised Rokumeikan for its use of nihilistic themes and its well-crafted dramatic structure. Tsujii wrote that Rokumeikan expresses Mishima's view of the nihilistic world where the traditions and values of Japan have completely unraveled. Mishima predicted that the nihilistic world would begin after World War II (Tsujii, 1988). But in fact, Tsujii believes that this drama clearly demonstrates that the nihilistic world had begun in the early Meiji era.

Isoda Kôichi (1967) explored the meaning of death in Rokumeikan by analyzing the way the characters died. Isoda wrote that Mishima recognized that mortal humans have the potential for immortality. Isoda assumes that both Einosuke and Hisao are shot and killed at the end of the play. By losing Einosuke and Hisao, Asako and Akiko feel that the love of these men belongs to them forever. This way of acquiring someone's love is not a practical solution for most people. Isoda understood Hisao's way of dying was Mishima's indication that rather than physical revenge, psychological revenge is more 
brutal and deadly. Isoda believes that Hisao appears to be plotting to kill his father, but in fact, he was planning to get killed by his father on purpose, thus satisfying his thirst for revenge. This creates a catastrophe, and Hisao's way of dying strongly impacts the audience. Isoda believed that the paradox of humanity in this story showed Mishima's conviction that human beings are non-humanistic.

Okuno Takeo (1958) approached Rokumeikan from an aesthetic perspective. He argued; "It is pointless to explore profound themes or meanings in this play. I believe Mishima concentrated on creating thrilling experiences for audiences just like he did in other conventional dramas. Mishima's play construction fuses form and beauty" (Okuno, 1958). Okuno (1958) explains the appeal of Rokumeikan in two ways; the beauty of the dialogues and the splendid historical backdrop of the play. Okuno praised Mishima's beautiful Japanese prose, which was a typical of other shingeki plays (Okuno, 1958). Okuno stated that Mishima's use of antique, formal Japanese language allowed the play to produce a captivating vision of the Meiji Era aristocratic world (Okuno, 1958). He also praised the success of Mishima's depiction of the Rokumeikan's history; a time that was both fragile and extravagant. Okuno considered the beauty of Rokumeikan, but came to no profound conclusions about Mishima's political or psychological agendas. Okuno's conclusions raise doubts about analyzing Rokumeikan critically.

Shibusawa Tatsuhiko (1967) connected politics with the Oedipus complex in Mishima's plays. Shibusawa wrote that Rokumeikan is a masterpiece of drama which clearly depicts the conflict between politics and love in an oedipal situation. Shibusawa's notion of the Oedipus complex maintains that a young man's pure dreams and 
romanticism will be destroyed by his father's cunning intrigues and betrayals. The son becomes rebellious against his father, and the mother takes the son's side. In Rokumeikan, Asako stands on both sides in order to prevent tragedy between her former lover, Einosuke Kiyohara, and her son, Hisao. However, Einosuke Kiyohara's unintentional emotional distancing causes Hisao frustration, which invites tragedy. At the beginning of the play, Hisao was planning to kill his father. But in the end, Einosuke Kiyohara kills his own son without realizing it, just the opposite of Oedipus who kills his father. In association with the Oedipus complex, Shibusawa, in his analysis of Hisao, mentions Mishima's yearning for a death like Saint Sebastian. Saint Sebastian was loved by the Roman Emperor, Diocletian. Disobeying Diocletian and the policy of Rome, Sebastian converted people to Christianity. Saint Sebastian's resolve to further the Christian movement led to his desire for self-destruction. Shibusawa (1967) says this image corresponds with Hisao who feels frustration in his life and commits rebellious acts. Shibusawa considers that one of the important keys to understand Mishima's plays is to understand the relations between his plays and the Oedipus complex. It is important to remember Mishima's affinity for Saint Sebastian.

Dômoto (1994) analyzed the psychology of Rokumeikan focusing on how major characters use their sexuality as a tool to gain status and maintain their social station, often through manipulation. Dômoto explored the world of deception in Rokumeikan, describing two separate spheres: Kageyama's political world and the women's world; Asako's geisha society. Dômoto (1994) perceived the sexuality in each character and tied their sexual appeal to their problems and to their deceptive actions. Dômoto stated that 
the world of courtly intrigue is made up of people of two kinds, those who behave nobly in life, and those originally born into aristocratic societies. Among those of the aristocratic social class is the Countess Daitokuji Sueko. She admits the mutual necessity of "lying to protect ourselves." It is in the blood of court aristocrats and the newly arisen aristocracy to behave this way. This is how they protect their status. Both Asako and Count Kageyama betray each other, but they are aristocratic enough to take betrayal in stride (Dômoto, 1994). Both of them mask their feelings to each other until the time tragedy occurs. In Dômoto's essay, love, sexuality, and betrayal are interconnected, but he makes it clear that betrayals happen not only because of sexuality and love. Betrayals and plots are necessitated by the difference in power among people, and by the different types of truth existing in society.

Sexuality is one of the key factors, however; this is not the main reason for the falsity and deception in this drama. In 1956, when Rokumeikan was published, Michael Foucault's philosophy, Truth and power (1977) had not yet been published, but Mishima's Rokumeikan seems ahead of its time in its support for Foucault's philosophical viewpoints concerning power and truth. It is useful therefore to analyze Rokumeikan in light of power and truth as they are explained by Michael Foucault. 
Critical Analysis Based on Western Literary Theory: Power, Truth, and Sexuality in Michel Foucault

Among Western theorists, I have chosen Michel Foucault to guide my analysis of the relationships in this play involving power, truth, and sexuality. In Truth and Power (1977), Foucault (1977) states that power itself has no origin, but is a distribution within the social system. He describes how historical constructions shape ideologies. Power is everywhere. For Foucault, truth is the product of power relations; people are part of a hierarchy of power relationships, and the ideology of the hegemonic entity that dominates the relationships becomes truth. Shifts among groups that exert power lead to changes in who has authority over what truth is. Ideology is the system of deciding truth based on economic life. Power shifts according to societal needs, and truth also varies as social systems change. According to Foucault, sexuality is also a product of power. One example Foucault gives is that, “... the situation that defines a woman is as someone whose fulfillment as a person is supposed to lie in a sexual relationship with a man (Culler, 1997, p.8).”

In Rokumeikan, I will analyze how sexuality and truth are created by the power relationships among Count Kageyama, Asako, Kusano, Einosuke Kiyohara, and Hisao. To analyze Rokumeikan using the conceptual framework of Michel Foucault, we accept the fact that truth and sexuality are created by power. Ideological truth is created by political and economic power. Foucault's notions of power of course include direct exercise of political power. 
Count Kageyama has four sources of power: high social status, wealth, formal political authority, and gender dominance over various women. Rokumeikan, the building itself, is an emblem of Count Kageyama. Rokumeikan shows his vast power, and at the same time stands as a metaphor for the emptiness of his soul. Count Kageyama is the Prime Minister; he possesses intelligence, wealth, and almost absolute power. With his power based on his wealth and his masculine domination of his maid, he extracts the hidden truth from her, and from other sources. His power elicits and creates truth. Count Kageyama coaxed Kusano with money and sexual dominance to make her expose the truth regarding Hisao, Einosuke, and Asako. The truth cannot be hidden from Count Kageyama because he is able to wield his power everywhere in order to learn what he needs to know and get what he wants. Count Kageyama acquired his wife with his high social status and power. His wife, Asako, used to be a highly reputed geisha in Shimbashi. Asako states clearly to her son "I have never yearned for anyone but your father (Sato tr., 2002, p. 16).” For all her life, Asako loved Einosuke Kiyohara, not Count Kageyama, however; she chose Count Kageyama for her marriage. Count Kageyama could have any woman he wants because of his power. Count Kageyama is able to manipulate people's inner feelings up to a certain point; he has married Asako and even obtained Kusano as a lover and informant. Even though Asako married him, her heart does not belong to him. Kusano belongs to Kageyama because Count Kageyama has high social and political rank, economic power, and superior gender status. Since Kusano asks Kageyama about her beauty, Kusano seems to have feelings for Kageyama, but it is not a strong feeling because Kusano is at the same time is confirming that Kageyama will give her a house and money. 
Kegeyama is secretly plotting to assassinate Einosuke Kiyohara. By knowing Hisao's grudge against his father, Count Kageyama can use Hisao's feelings to manipulate Hisao into killing Einosuke, which will in fact serve Count Kageyama. He does this because if Hisao kills Einosuke, it will appear to be a family feud and not Count Kageyama's doing. Using the truth of the grudge between Einosuke and Hisao, Count Kageyama attempts to manipulate people's actions using his power. Truth, power and sexuality are strongly connected. Truth is linked in reciprocal relation with systems of power that produce and sustain it. Truth is a creation of the economical and political dominance that is exerted by those in power within the social network.

Asako's sources of power are similar to Kageyama's: her sexuality, high social status and wealth. However, her social status in the past was not high. Asako's previous status threatens to drag her down and casts a big shadow over her. Asako is a powerful woman who gained her authority from being the wife of Count Kageyama, the Prime Minister of Japan. As mentioned above, Asako used to be a geisha in Shimbashi. She was reputed for her beauty, poise, and charm. Even though as a geisha, she did not have high status in society, she mingled with Japan's most powerful political leaders. She is portrayed as a conservative traditionalist who cherishes old Japanese customs, fashions and values. Without a man's support; she is socially vulnerable, because of her low social status. A woman's beauty and charms are powers that a man does not have. After getting married to Count Kageyama, her power and authority expand greatly. She receives power and authority from him. Asako uses her intelligence and sexual attractiveness to appropriate a portion of a man's power, thus making her a "successful woman." This 
closely matches Foucault's definition of a women's status about performing gender. Nonetheless, Asako cannot become stronger than Count Kageyama. Without him, she is powerless; therefore even after her own child dies, and her lover, Einosuke Kiyohara loses everything, she stays with Count Kageyama. She loves Kiyohara but Asako's love is not strong enough to induce her to give up her power and place in society. Asako suppresses her feelings and has to be passive in front of Count Kageyama (Honda, 1970). As Asako used to be a Geisha, she is skilled at using various strategies to manage relationships.

Sueko: "But isn't the geisha world a world of lies and calculations? (Sato, 2002, p.8)"

Sueko: "But that's where weak women tell lies only to protect themselves. She dislikes going to official places because there women, like men, learn to tell lies voluntarily (Sato, 2002, p.8)."

Hypocrisy is a required modus operandi for a geisha, but prevarication does not enable Asako to create a successful defense strategy in this play. The more the play progresses, the more Asako becomes absorbed into Count Kageyama's political and social values. Asako tries to use her power to protect her former lover and her son, but because her husband is bent on destroying them, but her power is insufficient and her efforts are in vain. She has to settle for being with Count Kageyama and lose these two men whom she dearly loves. She represents the ideals of romantic and maternal love that are defeated by the reality of political power. 
The maid Kusano does not have money or high social status, all she has is sexuality. Kusano is socially vulnerable, and she has no power in society. She is a maid and with her status she cannot obtain what she desires. However, being a maid at Count Kageyama's residence and knowing the truth about Asako gives her some power. In her case, truth gives her power, but without Count Kageyama, she is powerless. Count Kageyama uses his social status to coax the truth from Kusano. Bribing her with money also helps. Kusano's small allotment of power results in financial gain for her. Kusano's sexuality serves to gain attention from Count Kageyama. He uses her to fulfill his physical needs and to gain crucial information. Knowing the truth about Asako and being Kageyama's secret mistress give Kusano temporary power. Count Kageyama wields the power and sexuality over both Asako and Kusano.

Einosuke Kiyohara has money, sexuality, and high social status; however his social status is low compared to Count Kageyama. As an opposition party leader fighting against to Count Kageyama's regime, he must abase himself in the society to which he belongs. He does not have as much power as Count Kageyama, who is Prime Minister. In addition, Count Kageyama has fame and a high position in society from being a nobleman, as compared to Einosuke, who is a commoner. Einosuke is supposed to have power over Hisao, but because of Hisao's grudges against his father, he does not allow Einosuke to exert full power over him. In fact, Hisao left the house suddenly without telling anything to his family and no one knows where he is or whether he is alive or not. Einosuke's weak point stems from his relationship with his son. Count Kageyama takes advantage of this weakness and uses it in his conspiracy to assassinate Einosuke. He will 
induce Hisao to assassinate Einosuke. Einosuke's love for his son is destroyed by Count Kageyama's power. One thing Kiyohara possesses which Count Kageyama does not have is Asako's love. This does not give Einosuke power; however this truth irritates Count Kageyama, and induces him to wield power in a more violent ruthless manner.

Hisao has sexuality, money, and a certain level of status by being the son of Kiyohara; however his status was unstable as he did not know the identity of his birth mother. Hisao is one of the remnants of the Jiyû Party (Liberal Party), but he does not support his father's idealism. Hisao has complicated feelings toward his father. Even though Hisao is Einosuke's son, he has grown up without knowing his mother. In his family, he was treated differently in his childhood and gradually, he started to suffer an inferiority complex, believing he did not receive family benefits due to the circumstances of his birth. His desire to be loved by his father gradually changed to hatred of his father. After many years, his hatred toward Einosuke gives him power within political society. Hisao met Count Kageyama, who holds the highest position in the political world, and by joining forces with him, Hisao gained power in political society. Einosuke is a worker within the political opposition to Count Kageyama's regime. Hisao, in his hatred for his father, unwittingly supports Count Kageyama. Count Kageyama uses Hisao's feeling of hatred toward his father for his own conspiracy. By allying with Count Kageyama, Hisao gains some political power. Lacking love and family ties, Hisao lacks emotional stability. Akiko and Hisao are in love, but this is not enough to prevent the tragedy, which will happen between him and his father. Hisao and Einosuke never engage in a parent-child 
connection in the play. Their relationship is political not familial. It becomes a political power struggle.

In considering the five characters of Count Kageyama, Asako, Kusano, Einosuke Kiyohara, and Hisao, I showed how truth and sexuality are tightly connected through power. Power can be achieved through sexuality and can produce truth. For example, Asako uses her power, specifically, her intelligence and sexual attractiveness, to influence Count Kageyama, who has the highest social status in Japan by getting him to marry her. Asako has successfully gained her own power in society. According to Foucault (1990), sexuality has recently become a device of power; its use has been expanding at an increasing rate since the seventeenth century. In conclusion, power is everywhere. Truth and sexuality are tightly connected through power relationships, as defined by dominant social and political ideologies.

According to Foucault, "there is no absolute truth but there are many ideas or interpretations of truth (Sakurai, 2001, p.29)," and we are all unconsciously controlled by the courtesy, custom and tradition, which are established by the powerful within society (Sakurai, 2001). 
What Creates Truth in Rokumeikan? Power or Love?

As Foucault maintains truth is created by power. Widely accepted truth is always created by the political power of the highest authorities in society. In fact, the ruling political regime is at the center of society in the real world in any country. Political regimes define or control reality, morality, and truth. Mishima portrays this political reality in Rokumeikan. As Prime Minister, Count Kageyama can wield his power and control people's actions around him. Kageyama's status and political power as Prime Minister enable him to marry the beautiful geisha, Asako, coerce the truth from Kusano, and put into motion plots to eliminate his political rival, Einosuke Kiyohara. Kageyama's power allows him to use Hisao to assassinate Hisao's father, Kiyohara, leaving Kageyama free to deny any involvement. Unfortunately for Kageyama, because of Hisao's unexpected actions, the plan to assassinate Einosuke is jeopardized. But no one ever knows Kageyama attempted the assassination. Kageyama has the power and political organization that allows him to create truth.

Foucault's notion of truth as created by power is by no means universally accepted. Normative social and moral values and traditional religions consider truth to be absolute, and not power-based. As powerful as most established religions are, the rationale for their morality and truth is the words of divine beings seeking to help all humans, rich and poor, weak and powerful. "For example, in the United States Christian truth supplanted Native American animistic truth because European civilization was socially, politically, and militarily more powerful. But Christians do not believe in the truth of Christ because their civilization is powerful. They believe that Christian truth is 
the word of God, the same now as it was when Christianity was a weak, persecuted religion in ancient Rome, and valid for all humans, weak or strong, at any time or any place (L. Kominz, personal communication, July, 21, 2010).” In addition to the truth created by power and religion, there is truth created by emotion, known to Japanese as ninjô. Ninjô refers to human feelings (especially love). "The most well known is maternal love. Numerous incidents recount how mothers risk their lives to protect their children, in defiance of social, political, and military power (L. Kominz, personal communication, July, 21, 2010)."

If Rokumeikan accepted at face value truth created by political power, it would not have been a popular play for over a half century. A play presenting only power-based truth cannot move the audience's hearts. Why is it that Rokumeikan has been remounted so many times?

In this play the tension between emotional truth and political power-based truth provides the drama. In traditional Japanese drama, ninjô is constantly in conflict with giri, which means duty. Giri is defined as follows: "giri is a duty or obligation of a person to behave in certain prescribed ways towards another to whom the person is indebted (Smith, 1983, p. 45)." Those in weak social positions owe giri obligations to those in position of power. Giri is the feeling of obligation toward powerful people with whom one has personal, unequal relationships, i.e. wife to husband, son to father, vassal to lord. Foucault's power is social and political authority, which may not have a personal connection to those whom it affects. Therefore, the psychology of this power relationship differs from giri. Both forms of power create social and political truth. 
For human beings, there are truths which are independent from the power in society. Truth based on power is mainly rational. But the human heart cannot always be controlled by reason. Mishima's Rokumeikan contains the conflict between the notions of giri and ninjô evident in Japanese culture. Asako understands the utility of submitting to Kageyama's truth and so she is willing to stay with him. However, Asako does not accept all the implications of Kageyama's power-generated truth. She fights with Kageyama because her feelings, "truth", are based on ninjô, are jeopardized by his "truth." This doesn't mean she seeks to gain political power over him. Because of her motherly instincts, she will protect Hisao at all costs; even if it means opposing Kageyama and endangering her own social status. Love creates truth for Asako, and political power creates truth for men in this play.

Truth created by ninjô appears to be the key to understand the popularity of this play. Asako's difficult interpersonal relationships and conflicted emotions connect her to the audience. All of us have personal conflicts in our relationship with others. To the audience, Asako is a flawed mother because she did not raise her child, and her feelings for her former lover betray her obligations as a wife. Despite her guilt for neglecting her familial duty, she resolves to act on her love for Einosuke Kiyohara and for Hisao. Asako's conflict between duty and her intricate feelings of love and familial responsibility allow the audience to relate to her. Asako's perseverance also fosters empathy with the audience.

Asako's personal truths are in emotional conflict with Foucault's idea of truth. Political power is crucially important and dominant in our society, but contrary to 
Foucault's persuasive socio-political interpretation of truth, personal and emotional interpretations of truth often conflict with the truth that political authorities force upon society. We all understand these contradictions in our life and this dilemma often leaves people feeling pain. The audience's feeling of empathy for Asako's suffering is the foundation for the popularity of this play. Asako's real feelings of human love in Rokumeikan —occur as she fights against dominant male authority, and this appeals to audiences. Although Asako cannot achieve what she wishes in the end; she does not let her difficulties defeat her. Observing all of the contradictions in her life and seeing all the unfairness and inequality in the world, audiences feel empathy with Asako and this has led to numerous successful productions of the play in the last half-century.

Various kinds of truth exist in this play. There is no doubt that Foucault's philosophy of power and truth is presented in Mishima's Rokumeikan, but Mishima also incorporates the conflict between giri and ninjô in this drama, adding richness to the story. Mishima leads his audiences to think about the implications of absolute power in political society. Emotions like love can defy even power which seems absolute. Besides Michel Foucault's concept of truth deriving from social and political power, this play suggests another source of power which challenges this authority. This is ninjô, the feeling of love. 


\section{Conclusion}

Though Mishima Yukio was most famous as a novelist, he had a rich and successful career as a playwright. Rokumeikan was his greatest stage masterpiece and among the most popular multi-act Japanese plays in the Post-War period. At Jiyû Gekijô alone, this tragic melodrama has been performed more than 200 times and drawn more than 96,000 viewers from 2006 to 2009 . Overall, more than a million people have seen it performed in the half a century since it was first produced.

Rokumeikan includes complex ideas about the relationship between truth and power. Foucault's theories were published well after this play was written, but Mishima had witnessed radical shifts of truth and power as war time Imperial Japan gave away to the U.S. Occupation. The creation of truth by the politically powerful was very apparent to him. For Mishima, political and social truth is a product of history, but truth for the individual is not so simple.

In the play, Prime Minister Count Kageyama has the power and authority to create truth and exercise his will in almost all endeavors and domains. But he cannot exert this power over his wife Asako. She cannot accept his truth or support his political machinations. For her, love for her son and a former lover exert more power than political authority or social duty. This conflict is similar to giri and ninjô in traditional Japanese plays_-it taxes her intellect, tears her heart, and ends in tragedy.

There are many superior qualities that contribute to this fine play: Mishima's classical elements in the shingeki format, rich stage setting, fascinating characters and their complex relationships, and intricate plot lines. Moreover, this play has been 
cherished by all the actresses who have performed Asako. Mishima stated that he intended this play "to showcase actors and acting (Mishima, 1956 b)." In Rokumeikan, Foucault's theory of power and truth is well portrayed, but at the same time this play presents different but overlapping loci of power and truth, in the private realm and in the public arena. In the play, Kageyama's concept of truth is similar to Foucault's idea. He elicits and creates truth by wielding political and social power and authority. Asako's idea of truth, however, is not affected by political and social power. For her, political power is important, but not as much as her maternal feelings of love towards her son, and her romantic love for Einosuke. In the vocabulary of traditional Japanese drama theory, for Asako, the power of ninjô is greater than the power of giri. Asako's dilemma of love and political power is the essence of the ongoing appeal of this play. Asako is not strongly positioned in society, but for love, she challenges the Prime Minister Count Kageyama, the most powerful man in the political regime. Asako is ready to face challenges and willing to take risks for her love. Count Kageyama forces Asako to submit to his power at the end of this play and destroys Asako's hopes and plans. Even though Asako struggles, she yields nothing. Her brave attitude, fighting for love, fascinates the audience. Asako's confrontation with Kageyama's patriarchal, authoritarian truth allows ordinary people in the audience to strongly empathize with the heroine. In the play, the viewers may reflect on the struggles they face in daily life, and project their own feelings into the play. What has made this the most popular play in post-war Japan is empathy for a woman in very difficult web of human relationships involving love and duty in conflict.

In conclusion, this play has been popular for over half a century, because of the conflict between power and truth, and feelings of ninjô (love). This dilemma induces 
audiences to feel empathy for the play's heroine, Asako, and accounts for the play's popularity during the last half century. 


\section{References}

Asukai, M. (1992). Rokumeikan building. Iwanami shoten: Japan

Butler, J. (1988). Performative Acts and Gender Constitution: An Essay in Phenomenology and Feminist Theory, Theatre Journal, Vol. 40, No. 4, pp 519-531

Culler, J. (1991). Literary Theory - A Very Short Introduction. New York: Oxford.

Dômoto, M. (1994). Gekijin Msihima Yukio. Tokyo: Geki Shobo.

Endo, S. (1958, October 1). Shimpa Engi e no Gimon to Iken. Higeki Kigeki, pp. 149173.

Foucault, M. (1977). Truth and Power. In A. Hazard \& L. Searle (Eds.), Critical Theory Since Plato: Third Edition (pp.1269-1279). Boston: Thomson Wadsworth.

Foucault, M. (1988). Power and Sex. In L. D. Kritzman (Eds.), Politics, Philosophy, Rutledge.

Foucault, M. (1990). The History of Sexuality. New York: Random House.

Honda, S. (1970). Rokumeikan ron. In Hasegawa, et al. (Ed.) Mishima Yukio Kenkyu (pp.289-304). Tokyo: Ubumi shoin 
Ikeda, K. (1967). Meiji 100 nen to Mishima Yukio -Showa no Yamagata Aritomo-. In NLT, NLT program No.6. (pp. 27-29). New Literary Theatre.

Isoda, K. (1967). Shôchô teki satsujin to gendai - Rokumeikan no ningen gaku-. In NLT, NLT program No.6. (pp. 25-27). New Literary Theatre. Japan Arts Council. (2007). Geza. Retrieved April 4, 2010, from Expression in Kabuki: http://www2.ntj.jac.go.jp/unesco/kabuki/en/4/4_05_01.html

Keene, D. (1967). Karei naru Yuki no Jidai. In NLT, NLT program No.6. (pp. 10-11). New Literary Theatre.

Keene, D. (1988). Rokumeikan Jidai to Mishima Yukio. In Shochiku Gendai Geki, Shôchiku Gendaigeki Mishima Yukio program. (pp.19-20). Shôchiku.

Kominz, L. (2007). Mishima on Stage The Black Lizard and Other Plays. The Center for Japanese Studies, The University of Michigan: Ann Arbor.

Matsuura, T. (1956). Kansô. In Bungaku-za, Bungaku-za

Program 20th Anniversary. (pp. 10-11). Bungaku-za.

Mishima, Y. (1956 a). Rokumeikan. Tokyo: Shinchôsha.

Mishima, Y. (1956 b). Rokumeikan ni tsuite. In Bungaku-za, Bungaku-za

Program 20th Anniversary. (pp. 4-5). Bungaku-za. 
Mishima, Y. (1959). Ratai to Ishô. Tokyo: Shinchôsha.

Mishima, Y. (1962). Jisaku Kaidai. In G. Shimpa, Shimpa Program 1962. Shimbashi Enbujo, Tokyo: Gekidan Shimpa.

Mishima, Y. (1967). Rekishi teki Daizai to Engeki. In NLT, NLT program No.6. (pp. 4-5). Neo Litterature Theatre.

Mishima Yukio Literary Museum. (2007). Mishima Yukio Daihyo Sakuhin. Retrieved July 25, 2010, from Mishima Yukio Bungakukan: http://www.mishimayukio.jp/sakuhin36_1.html

Naramoto, T. (1956). Rokumeikan no Rekishiteki Haikei. In Bungaku-za, Bungaku-za Program 20th Anniversary. (pp. 14-15). Bungaku-za.

“ninjô". (2010). In Encyclopedia Britannica. Retrieved June 03, 2010, from Encyclopedia Britannica Online: http://www.britannica.com/EBchecked/topic/415749/ninjô

Noguchi, T. (1968). Kamen no Soumenshin -kamen no kokuhaku ron-. In S. Masayoshi, Hihyou to Kenkyu (pp. 203-222). Tokyo: Haga Shoten.

Nomura, R. (2009, September, 23). In Takubo, S. Rokumeikan Nomura Reiko san interview. Retrieved July 20, 2010, from Sankei Express: 
http://www.iza.ne.jp/news/newsarticle/entertainment/stage/304849/

Okuno, T. (1956). Rokumeikan ni tsuite. In Bungaku-za, Bungaku-za Program 20th

Anniversary. (pp. 10-13). Bungaku-za.

Okuno, T. (1958). Shoen Rokumeikan wo mite. In Bungaku-za, Bungaku-za

Program $5^{\text {th }}$ Charity Show . (pp. 5-6). Bungaku-za.

Okuno, T. (1993). Mishima Yukio densetsu. Tokyo: Shinchô sha.

Ôzasa, Y. (1995). Joyû Sugimura Haruko. p.193, p.258. Tokyo: Shueisha.

Rokumeikan ni tsuite. (n.d.) (2009). Retrieved July 10, 2010, from

http://musicallove.blog.so-net.ne.jp/2009-08-12-5

Sakurai, T. (2006). Chi no kyôkasho- Foucault. Tokyo: Kodansha

Shiki Theatre Company. (2009 a). Shiki e-plus ticket Rokumeikan. Retrieved

September 1, 2009, from Shiki Theatre Company site: http://eplus.jp/shiki/

Shiki Theatre Company. (2009 b). Rokumeikan. Retrieved September 15, 2009, from

Shiki Theatre Company site: www.shiki.gr.jp/Rokumeikan/

Shiki Theatre Company. (2010 c). Gekidan Shiki Rokumeikan. Retrieved January, 27, 2010, from NHK entreprise. site: http://www.nhk-ep.com/shop/main

Smith, Robert J. (I983). Japanese society: Tradition, self and the social order. 
Cambridge: Cambridge University Press.

Takahashi, Y. (2009, November 25).Gendai wo utsusu gekijô: "shingeki 100 nen"

ni kangaeru. The Mainichi Newspapers, retrieved March 2, from

http://mainichi.jp/tanokore/art/002588.html

The National Theatre of Japan. (2009). Rokumeikan. Retrieved January 27, 2010, from

New National Theatre, Tokyo site:

http://www.nntt.jac.go.jp/english/opera/e20000196_2_opera.html

Sankei News. (2009, June 17). Gekidan Shiki Haiyu ga Hasseuhou wo Danju.

Retrieved July 20, 2010, from Sankei News Chiho:

http://sankei.jp.msn.com/region/kanto/tokyo/090617/tky0906172057003-n1.htm

Sato, H. (2002). My Friend Hitler and other plays of Mishima Yukio. New York:

Columbia University Press.

Setouchi, H. (1967).Asako no Miryoku. In NLT, NLT program No.6. (pp. 12-13).New

Literary Theatre.

Shibusawa, T. (1967). Sebastian Complex ni tsuite -Mishima Gikyoku no Soko ni arumono-. In NLT, NLT program No.6. (pp. 23-25).New Literary Theatre.

Sugimura, H. (1959). "Rokumeikan.” In Uchimura, N. \& Yoshimura, Y. (ed.) Gendai 
Engeki Kôza No.3. (pp.205-209). Mikasa Shobô.

Tsujii, T. (1988). Rokumeikan no shudai. In Shôchiku Gendai Geki, Shôchiku Gendaigeki Mishima Yukio program. (p.25). Shôchiku.

Yamaguchi, R. (1988). Rokumeikan sawagi. In Shochiku Gendai Geki, Shôchiku Gendaigeki Mishima Yukio program. (pp.21-24). Shôchiku. 


\begin{abstract}
Appendix
Rokumeikan Performances Referred to in This Essay
\end{abstract}

First run was from $27^{\text {th }}$ November to $9^{\text {th }}$ December in 1956 at Daiichi Seimei Hall with Sugimura Haruko performing Asako and Nakamura Nobuo performing Kageyama. Mishima was a carpenter as a walk-on role. From $3^{\text {rd }}$ October to $28^{\text {th }}$ November in 1957 , Bungaku-za ran national tour at 35 places.

Gekidan Shimpa performed Rokumeikan from $2^{\text {nd }}$ to $26^{\text {th }}$ November in 1962, at Tokyo Shimbashi Enbujô. Mizutani Yaeko acted Asako and Mori Masayuki played Kageyama. Gekidan Shimpa also performed from $1^{\text {st }}$ to $25^{\text {th }}$ December in 1962 at Osaka Shin Kabuki-za and from $1^{\text {st }}$ to $25^{\text {th }}$ October in 1963 at Tokyo Meiji-za.

Gekidan Shiki first performed Rokumeikan from $14^{\text {th }}$ January to $12^{\text {th }}$ February in 2006 at Tokyo Jiyû Gekijô. Nomura Reiko performed Asako and Kusaka Takeshi performed. They also performed in 2009 from $14^{\text {th }}$ September to $10^{\text {th }}$ October.

From $24^{\text {th }}$ to $27^{\text {th }}$ June in 2010 , Ikebe Shinichiro directed the opera version of Rokumeikan. 